\title{
The Nature of Blood: Debating Haematology and Blood Chemistry in the Eighteenth-Century Dutch Republic
}

\author{
Ruben E. Verwaal \\ University of Groningen \\ r.e.verwaal@rug.nl
}

\begin{abstract}
What is blood? Despite William Harvey's discovery of the circulation of blood, many questions about blood itself remained unanswered. This article asks how and why Dutch medical men in the early eighteenth century initiated studies to understand the properties of blood. Medical professors analysed blood in chemical laboratories, as they believed that blood chemistry promoted new understandings of human physiology and pathology. Others, however, grew to be deeply sceptical about chemistry and argued that there existed a discrepancy between blood in vitro and blood in vivo. They preferred quantitative measurements, hoping that these would provide useful knowledge for making diagnoses and treating wounds. This article analyses these competing approaches to blood research, arguing that the discussion went beyond the problem of methodology and was directly linked to the question of blood's essential yet disputed quality: was blood alive?
\end{abstract}

* Groningen Research Institute for the Study of Culture, Oude Kijk in 't Jatstraat 26, 9712 EK Groningen, The Netherlands. This paper is part of the "Vital Matters" research project funded by the Netherlands Organisation for Scientific Research (NWO). Early versions of this paper were presented in 2015 at the SHAC Spring Meeting in Cambridge, at the Huizinga Institute in The Netherlands, and at the annual meeting of the History of Science Society (HSs) in San Francisco. I am particularly grateful to Rina Knoeff, Raingard Esser, Catrien Santing, Hasok Chang, Charles Wolfe, and the two anonymous reviewers for their helpful comments on earlier versions of this paper. 


\section{Keywords}

blood - chemistry - haematology - medicine - Hieronymus Gaubius - Thomas Schwencke - Herman Boerhaave - Pierre Bordeu - Julien Offray de La Mettrie

\section{Introduction}

Blood, that warm, red fluid running through arteries and veins to every part of the body, was a subject of considerable debate in the Dutch Republic. Although William Harvey (1578-1657) had already demonstrated in 1628 that blood circulated in the human body, even a century later, anatomical studies of the circulatory system still could not explain the nature and properties of blood itself. In their attempts to understand the nature of blood medical men in the Dutch Republic increasingly relied on chemistry, but as we shall see, their approach was not universally accepted. Medical professors at Leiden University such as Hieronymus David Gaubius (1705-1780) were confident that chemistry could indeed uncover blood's true nature, arguing that chemical investigations would reveal its constituent parts. But others, most notably Thomas Schwencke (1694-1767), a city physician from The Hague, argued that there existed a fundamental difference between blood in vitro (in glass) and blood in vivo (in the living body), and therefore seriously doubted the merits of a chemical approach. This article argues that the disagreement about how to research the nature of blood allows us to understand important issues in early eighteenthcentury medicine, in particular the definition of bodily fluids, the increasingly important role of chemistry in medicine, and the apparent rivalry between mechanist and vitalist approaches to physiology. ${ }^{1}$

The notion of blood as the most important bodily fluid existed for many centuries. ${ }^{2}$ Yet it was only at the turn of the eighteenth century that the actual nature and function of blood in the so-called 'animal oeconomy' became the subject of extensive chemical and empirical study. Blood raised a multitude of questions that were avidly debated by medical men: what was the relationship

1 On the purported dichotomy between mechanism and vitalism, see Anita Guerrini, "James Keill, George Cheyne, and Newtonian Physiology, 1690-1740," Journal of the History of Biology, 18 (1985), 247-266. On modern misconceptions of vitalism, see Charles T. Wolfe, "From Substantival to Functional Vitalism and Beyond: Animas, Organisms and Attitudes," Eidos, 14 (2011), 212-235. Wolfe and Terada encourage scholars to instead focus on animal economy or physiology in Charles T. Wolfe and Motoichi Terada, "The Animal Economy as Object and Program in Montpellier Vitalism," Science in Context, 21 (2008), 537-579.

2 Noga Arikha, Passions and Tempers: A History of the Humours (New York, 2007). 
between the movement of blood and its unique ability to coagulate? What were the differences between blood in sick and in healthy bodies? And, most importantly: was blood alive? Studying blood thus allowed Dutch physicians to approach some of the biggest questions concerning the mechanisms of life.

The contemplation of blood brought into contact theories of physiology and pathology with practices from experimental and observational traditions. Blood provides a particularly fruitful case for historians aiming to explore questions of methodology in eighteenth-century medicine, specifically the relationship between medical theory and experimental practices, since it required medical researchers to seek out new ways in their attempt to understand its workings. Gaubius and Schwencke observed that blood flowing through the arteries and veins of the living body remained firmly fluid and homogeneous, but began to clot once gushing out of a ruptured vessel. Recognising that the anatomical studies of the circulatory system could not explain the nature and properties of blood itself, they subjected blood to measuring instruments and chemical apparatuses. Schwencke's and Gaubius' studies of blood serve as a basis for the argument in this present article that their debate on the nature of blood, in effect, spurred innovative interactions between medical theory and experimental research.

Scholars of the most recent decades have shifted their attention away from the circulation of blood towards blood itself, asking how physicians understood its properties throughout history. ${ }^{3}$ Domenico Bertoloni Meli, for example, has traced the problems facing seventeenth-century physicians debating the value of colour indications as evidence of the essential properties of blood. ${ }^{4}$ Andrew Cunningham has shown that in England blood did not become a serious subject for research until the second half of the seventeenth century. ${ }^{5}$ Although Harvey never intended to research the nature of blood itself he granted it precedence over the heart as the source of bodily activity, warmth, and life in his Exercitationes de generatione animalium (1651). Both

3 Maxwell M. Wintrobe, ed., Blood, Pure and Eloquent: A Story of Discovery, of People, and of Ideas (New York, 1980); Douglas Starr, Blood: An Epic History of Medicine and Commerce (London, 1999). On circulation, see Roger French, "Harvey in Holland: Circulation and the Calvinists," in Roger French and Andrew Wear, eds., The Medical Revolution (Cambridge, 1989), 46-86; Roger French, William Harvey's Natural Philosophy (Cambridge, 1994).

4 Domenico Bertoloni Meli, "The Color of Blood: Between Sensory Experience and Epistemic Significance," in Lorraine Daston and Elizabeth Lunbeck, eds., Histories of Scientific Observation (Chicago, 2011), 117-134.

5 Andrew Cunningham, "The Principality of Blood: William Harvey, the Blood, and the Early Transfusion Experiments," in Catrien Santing and Jetze Touber, eds., Blood - Symbol - Liquid (Leuven, 2012), 193-205. 
Bertoloni Meli and Cunningham demonstrate that increasing attention was paid to blood and its physical properties in the seventeenth century, but they do not discuss the developments following the turn of the century. By contrast, Noel Coley's work reveals the advances made with the help of new instruments in clinical chemistry and haematology in late eighteenth-century England and France. Coley argues that these studies were inspired by the Dutch professor Herman Boerhaave (1668-1738), who "prepared the ground for the rise of a new form of humoralism, one in which the chemical composition of body fluids in health and disease would figure prominently." ${ }^{\prime 6}$ However, Coley considered Boerhaave in isolation from other Dutch medical men, implying that nothing else of importance happened in the Dutch Republic at the time. ${ }^{7}$

This article argues that the Dutch Republic was, in fact, crucial for the development of innovative blood research. Focussing on the physicians Thomas Schwencke and Hieronymus Gaubius, this article examines their proposals for blood chemistry and haematology respectively. Schwencke's haematology made detailed observations and measured properties of blood with thermometers and hydrometers. But since his results from these measurements differed significantly from Gaubius' chemical analyses Schwencke expressed a strong criticism against blood chemistry. This article concludes with the argument that this debate about the methodology of studying blood was linked directly to the ontological question of its essential yet disputed quality: was blood alive?

\section{Lifeblood}

Early modern physicians believed that blood was the most important bodily fluid, embodying notions of life and soul. Blood was seen as the nourishment for the body, the sustenance of health, and the source of all other bodily fluids. Medical professors repeated this notion in their lectures and textbooks often: Albrecht von Haller (1708-1777) commented on Boerhaave's lectures, "the red Fluid we call Blood [...] contains the Materials of all the other Juices found in every Part of the Body." In his chemical lectures Boerhaave himself hailed

$6 \quad$ Noel G. Coley, "Early Blood Chemistry in Britain and France," Clinical Chemistry, 47 (2001), 2166-2178, at 2167.

7 Cf. Lawrence M. Principe, "A Revolution Nobody Noticed? Changes in Early EighteenthCentury Chymistry," in Lawrence M. Principe, ed., New Narratives (Dordrecht, 2007), 1-22. Albrecht von Haller, ed. Praelectiones academicae in proprias institutiones rei medicae, 6 vols. (Göttingen, 1739-1744), 2: 325. "Sanguis ruber, crassissimus liquidorum humanorum, 
blood as the "perfect animal juice" and the "utmost universal humour," not just because blood raced to all corners of the human body, but also because, in his view, all other bodily fluids were derived from it. ${ }^{9}$ Schwencke and Gaubius both of whom had studied medicine at Leiden under Boerhaave in the $1710 \mathrm{~s}$ and 1720 s - represented the mainstream thinking on blood when they, too, observed that fluids flow "from the general ocean of blood," which was, as it were, "the common mother of them all."10

The primacy of blood was further supported by the belief that it directly influenced the passions (see fig. 1). Blood played a pivotal role in the interaction between body and soul, since mental disturbances were linked to bodily imbalances. Schwencke, for instance, observed that "in anger the pulse becomes large and rapid, and as a result the heat increases, as the thermometer demonstrates; but that there is a speedy and small pulse, accompanied with coldness, when one is frightened."11 When a woman's "excessive sexual desires" were out of control, Gaubius similarly advised that bloodletting would "weaken" and "cool" her, so that there would be no difficulty to "restrain her from her unlawful habits."12 Specific motions of blood were thus a direct manifestation

continet materiam omnium aliorum liquidorum, quae in corpore humano reperiuntur." Idem, Dr. Boerhaave's Academical Lectures on the Theory of Physic, 6 vols. (London, 17421746), 2: 175 .

9 Herman Boerhaave, A New Method of Chemistry: Including the Theory and Practice of that Art: Laid down on Mechanical Principles, and Accommodated to the Uses of Life, trans. Peter Shaw and Ephraim Chambers, 2 vols. (London, 1727), 1: 167. This is an English translation of Boerhaave's chemical lectures published without authorisation as Institutiones et experimenta chemiae (Paris [Leiden?], 1724). More so than Boerhaave's official textbook, Elementa chemiae (Leiden, 1732), this work reflects how students experienced the chemistry lectures at Leiden University.

10 Thomas Schwencke, Schets van de heelmiddelen en haar uytwerkingen op het lichaam (The Hague, 1745), 3: "uyt de algemeene oceaan van bloed." Hieronymus David Gaubius, Institutiones pathologiae medicinalis (Leiden, 1758), 155: "communis eorum veluti mater est." Idem, The Institutions of Medicinal Pathology, trans. Charles Erskine (Edinburgh, 1778), 103 .

11 Thomas Schwencke, Haematologia, sive Sanguinis historia, experimentis passim superstructa (The Hague, 1743), 68: "Quantum vero ex animi pathemate pulsus et calor, et hinc omnes profluentes effectus varient, breviter dicam: iratorum magnus et celer est pulsus, unde calor et aestus augentur ad Thermometrum; à terrore frequens et parvus cum frigore." Idem, Haematologia, ofte Verhandeling van het bloed, trans. Abraham Westerhoff (The Hague, 1744), 109-110. Duty and Office of Physicians in the Management and Cure of the Disorders of the Mind, trans. J. Taprell (London, c. 1760), 116. 


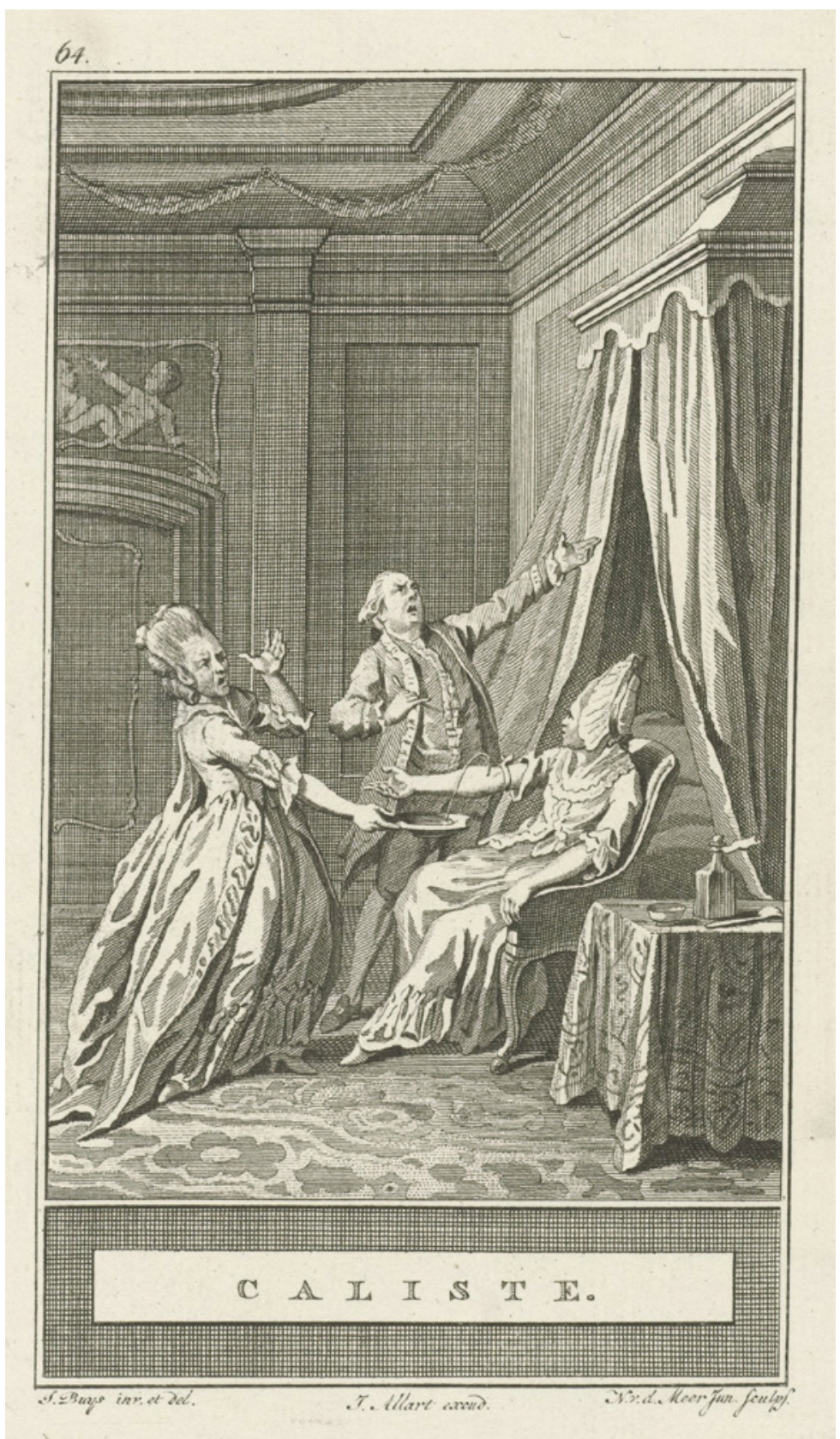

FIGURE 1 Lady Caliste bleeds to death after her physician's fatal mistake. Noach van der Meer Jr., after Jacobus Buys, illustration for "Caliste," in C.F. Gellert, Fabelen en vertelsels (Amsterdam, 1777). RIJKSMUSEUM, AMSTERDAM. 
of strong feelings and desires - and through the treatment of blood physicians were able to modify certain faculties of the soul directly.

These two notions of blood's primacy, namely as the 'mother of them all' and as the reflection of emotions, had ancient origins. In humoral theory, health and disease were understood to correspond to a balance or imbalance of the four essential humours: blood, yellow bile, black bile, and phlegm. In this system, the humours corresponded to the four Aristotelian elements (air, water, fire, earth), the four qualities (hot, cold, dry, wet) and the four temperaments (sanguine, phlegmatic, choleric, melancholic). Blood literally was the most sanguine of all four humours, allowing humans to be characterised by optimism, patience, and thoughtfulness - as opposed to being irritable or melancholic in the case of yellow and black bile. ${ }^{13}$ But the notions of ancient blood and early modern blood were quite different: in the early modern period the humours were related to, but not directly identified with specific fluids. Humoral theory was, above all, a rational and logical construct, and not necessarily grounded in observation and experience. ${ }^{14}$ In the course of the early modern period, however, physicians shifted their focus from humoral blood to blood as bodily fluid.

Finally, the primacy of blood appears in early modern physicians' notions of life. When Gaubius showed how blood clotted, he noted that "consistency of life and health therefore especially depends on an unimpeded transfer of blood, for blood can easily cross from a fluid state to a solid state."15 Schwencke was equally explicit in his discussion of the "juice of life."16 He argued that, when blood flowed out of a dog's body during vivisection, the functions of the soul - such as the will to move - also seeped away. Blood not only sustained life, but "it is said that the soul and the life are in the blood."17 These statements and experiments echoed Harvey's claim that blood was the agent of life, since

\footnotetext{
13 Arikha, Passions and Tempers.

14 Lawrence I. Conrad et al., The Western Medical Tradition: 80o BC to AD 1800 (Cambridge, 1995).

15 "Cl. Hier. Gaubii, in Academia Lugduno-Batava professoris extraordinarii et lectoris chemiae, praelectiones publicae chemicae annorum 1731, 1732 et 1733, sive examen chemicum humorum corporis humani, habitum in auditorio chemico," 2 vols, Bibliothèque universitaire de lettres de l'Université Michel de Montaigne, Bordeaux, Ms Bdx.U3.Ms.4, 1731-1733, vol. 2, p. 45: "Constantia ergo vitae et sanitatis unice pendet a libero trajectu sanguinis, nam facillime potest sanguis ex statu fluiditatis in soliditatis statum transire."

16 Schwencke, Verhandeling van het bloed, xxii: "levens-vocht." In the original Latin, Schwencke used the more generic term humor, but Westerhoff translated it as "juice of life." Westerhoff came from Gouda had also studied at Leiden, promoting in 1738.

17 Schwencke, Haematologia, 9: "hinc anima et vita dicuntur esse in sanguine." Italics added.
} 
if the blood stopped flowing to parts of the body, life in the entire body, or the relevant parts, would stop..$^{18}$ In blending medical and metaphysical notions of blood, then, these academic medical texts clearly show how blood was considered to be the primary bodily fluid, and to reflect one's passions, life and health. ${ }^{19}$

Despite the wide-ranging consensus over the primacy of blood, however, eighteenth-century physicians still faced intriguing questions concerning the nature and production of blood. What exactly was blood made of? And where and when did food loose its vegetal nature and transform into a liquid of an animal nature? The latter question was particularly complex - since Antiquity natural philosophers had generally divided the natural world into the vegetable, animal and mineral kingdoms, thus problematising the transformation from vegetal nourishment to animal body. In the eighteenth century, however, these separate realms were increasingly being questioned, as explorers discovered living creatures who exhibited characteristics of both animals and plants, such as freshwater polyps and coral. ${ }^{20}$ Consequently, physicians like Gaubius adopted chemistry as a method of investigation, hoping that it would help them to resolve the physiological problem of the nature of blood.

At the turn of the eighteenth century, experiments and hands-on observations to better understand the nature and production of blood were, indeed, incorporated in medical curricula at Dutch universities (see fig. 2). In Leiden, for example, medical students learned that blood developed from chyle, the milky fluid draining from the lacteals of the small intestine into the lymphatic system. As Boerhaave explained, chyle was extracted from vegetables during digestion, and therefore vegetal in nature. Yet when this chyle "is further prepared in the intestines, and received into the lacteals, [it] approaches more to

18 See for example William Harvey, Exercitationes de generatione animalium (Amsterdam, 1651), 304. "Quibus clare constat sanguinem esse partem genitalem, fontem vitae, primum vivens \& ultimo moriens, sedemque animae primariam; in quo (tanquam in fonte) calor primo, \& praecipue abundat, vigetque." Charles Webster, "Harvey's De Generatione: Its Origins and Relevance to the Theory of Circulation," British Journal for the History of Science, 3 (1967), 262-274, at 272. On Harvey's notion of the soul residing in the blood, see Christopher Hill, "William Harvey and the Idea of Monarchy," Past and Present, 27 (1964), 54-72; Ann Thomson, Bodies of Thought: Science, Religion, and the Soul in the Early Enlightenment (Oxford, 2008), 68-74.

19 The Scottish anatomist John Hunter (1728-1793) continued to reiterate the notion of blood as the necessary condition for life in his A Treatise on the Blood (London, 1794), 85: "Blood is not only alive itself, but it is the support of life in every part of the body." Susannah Gibson, Animal, Vegetable, Mineral? How Eighteenth-Century Science Disrupted the Natural Order (Oxford, 2015). 
the nature of an animal juice, and undergoing divers circulations therein, it becomes a perfect animal juice, and is called blood."21

Chemistry supported the notion that vegetal chyle was transformed into animal blood. Boerhaave had demonstrated that, when animal fluids were burnt, the ashes were found to be insipid, and the remaining salts volatile, whereas vegetal juices left fixed salts in all their ashes. Moreover, none of the animal fluids contained acid, whereas vegetal juices did. ${ }^{22}$ The Irishman John Ellis (c. 1710-1776) applied exactly this chemical process when he argued that vegetal-appearing corallines were, in fact, animal. He posited that corallines and plants differ in chemical production, "For Sea-Plants [...] afford in Distillation little or no Traces of a volatile Salt: Whereas all the Corallines afford a considerable Quantity."23 The chemical process of combustion thus provided a new method to properly distinguish between animal and vegetal materials. Chemistry also revealed close similarities between different fluids. When Gaubius analysed blood and milk in his lectures, he concluded that "when we compare the serum of the blood with the whey of milk, red blood with the cream, and the fibre with the curd, we find many things in common to both."24 Chemistry, in other words, allowed physicians to reveal constituent parts of different bodily fluids, and to differentiate more clearly between animal and vegetal bodies.

But not everyone was convinced of the merits of chemistry for furthering knowledge on the nature and the origins of blood. One of its fiercest critics was Thomas Schwencke. In the preface to his Haematologia (1743) he stated that "we have also shortly addressed the Chemical examination of the blood, but at the same time we reported the reason why a Physician by this way can never understand the natural character or condition of blood."25 The nature of materials obtained from blood by distillation, he argued, was different from that of

21 Boerhaave, A New Method, 1: 167. Emphasis original. Barbara Orland, "The Fluid Mechanics of Nutrition: Herman Boerhaave's Synthesis of Seventeenth-Century Circulation Physiology," Studies in History and Philosophy of Biological and Biomedical Sciences, 43 (2012), 357-369.

22 Boerhaave, A New Method, 1: 168.

23 John Ellis, An Essay towards a Natural History of the Corallines, and other Marine Productions of the Like Kind, Commonly Found on the Coasts of Great Britain and Ireland (London, 1755), 2.

24 Gaubius, Institutiones, 160. "Compara cum sero lactis serum sanguinis, cum cremore rubrum, cum caseo fibram! Multa invenies utrinque communia." Idem, Institutions, 106.

25 Schwencke, Haematologia, xi-xii. "Sanguinem Chemice tractatum [...] breviter exposui, reddidique rationem, cur per analysin notam indolem sanguinis naturalem nunquam comprehendet Medicus." Idem, Verhandeling van het bloed, xxi-xxii. 


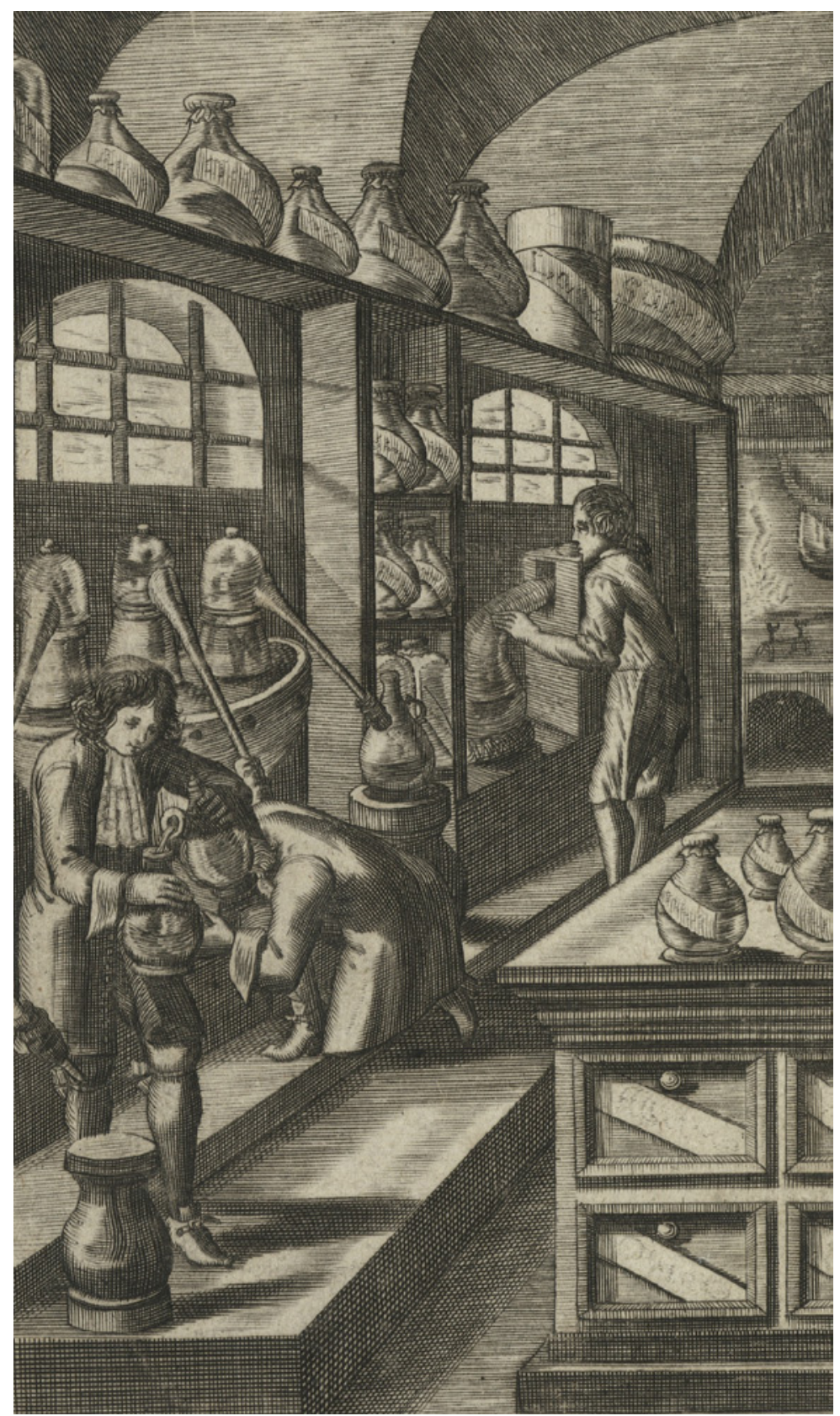

FIGURE 2 Students mixing and distilling fluids in the Leiden chemical laboratory, from Boerhaave, Institutiones et experimenta chemiae (Paris, 1724), frontispiece. GHENT UNIVERSITY LIBRARY. 
the living blood running though the veins. The difference of opinion between Schwencke and Gaubius manifested perhaps most clearly in their respective publications and lectures. Despite their different approaches to studying the nature of blood, Gaubius and Schwencke avoided direct confrontation, and did not reference each other directly in their arguments. Rather, Schwencke talked about "chemists" in general, or safely referred to "Boerhaave in his chemical work" who, by then, had passed away. ${ }^{26}$ Although an overtly hostile language characteristic of polemics was carefully avoided, the two authors' difference of opinion is nonetheless clearly apparent, as both Schwencke and Gaubius formulate their ideas and methodology very precisely.

\section{Blood Chemistry}

When Hieronymus Gaubius (see fig. 3) started his chemical lectures at Leiden University in 1731, as Boerhaave's successor, he affirmed that "blood is the liquid of animals, which proceeds from the heart into the arteries," yet hastened to add that "we cannot give a definition of its [blood's] own particular nature before we have investigated it by Chemistry." 27 Blood chemistry evolved in the course of the eighteenth century, and with its methods, chemists like Gaubius envisioned blood as a complex blend of rudimentary substances and principles. Chemical textbooks and lecture notes from this period all attest to the frequent experiments on blood that took place in the Leiden Laboratorium Chymicum, a modest space located in the botanical garden of the university (see fig. 2). ${ }^{28}$ These sources reveal that professors like Gaubius approached blood with chemical methods, teaching students how to experiment on blood, how to handle it, and how to determine its properties using instruments as well as their own senses. ${ }^{29}$

$26 \quad$ Ibid., xviii, 34, 82, 139, 252.

27 "Praelectiones publicae chemicae," vol. 2, p. 37: "Sanguis est liquor animalis, qui ex corde in arterias proficitur. Definitionem ejus ex propria ejus natura desumtam dare non possumus, antequam Chemice eam inquisiverimus." Emphasis added.

28 Besides Boerhaave's official chemical textbook Elementa chemiae (Leiden, 1732), students' lecture notes circulated widely, such as "Viri Clarissimi Hieronymi Davidis Gaubii [...], Dictata in Chemiam," Leiden: Philippus Bonk, c. 1750. University Library, Leiden, MS BPL 1477 .

29 Boerhaave is heralded for restructuring and reinterpreting chymical practices for the purpose of medicine and academic education by Rina Knoeff, Herman Boerhaave (1668-1738): Calvinist Chemist and Physician (Amsterdam, 2002); Ursula Klein, "Experimental History and Herman Boerhaave's Chemistry of Plants," Studies in History and Philosophy of 


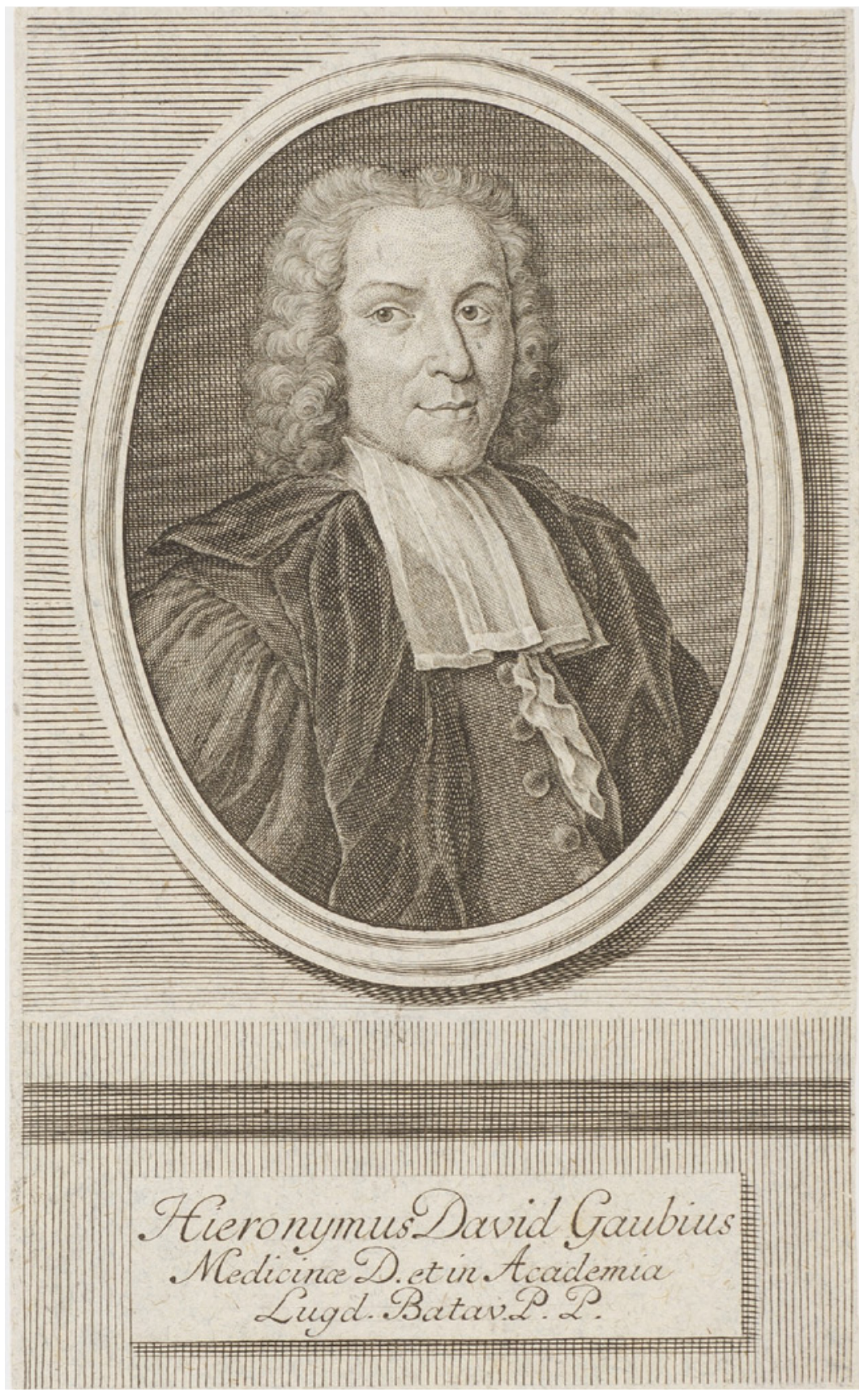

FIGURE 3 Jacob Houbraken, after Hieronymus van der Mij, portrait of Hieronymus David Gaubius, 1744. HERITAGE LEIDEN AND SURROUNDINGS. 
In the course of his own studies at Leiden between 1723 and 1725, Gaubius had learned about the use of chemistry in medicine from Herman Boerhaave, the renowned professor of medicine who had delivered regular lectures on the history, theory, and practice of chemistry until 1729. Boerhaave argued that the method of chemistry was essential to understanding physiology, because " $[\mathrm{n}]$ o-body but a chemist could say what kind of liquor the blood is." Medical students needed to extend beyond the anatomical structure of the body and explore the very materials of which it was made, because blood "exerts a force of its own; which chemistry explains, by shewing it possessed of certain active principles, as salts, spirits, oils, \&c." Once these active principles were known, "a chemist will nicely understand, and advantageously distinguish between the signs of health and sickness."30 Boerhaave's conception sharply contrasted Georg Ernst Stahl's opinion on the role of chemistry in medicine. While Stahl (1660-1734), a German chemist and physician, contributed significantly to the field of chemistry, and his work was widely read, ${ }^{31}$ he played a minor role in the blood chemistry of Boerhaave and Gaubius: his approach to medicine favoured the role of anima (soul) in health and disease over chemical principles of body parts. $^{32}$ Boerhaave and his medical students in Leiden embraced the work of Stahl's rival, Friedrich Hoffmann (1660-1742), instead, who had not only enriched the field of chemistry, but also recognised the service of chemistry to medicine. ${ }^{33}$ Hoffmann's best-known chemical work concerned the analyses of mineral waters, in which he identified aether, water, earthy, and saline compo-

Biological and Biomedical Sciences, 34 (2003): 533-567; John C. Powers, Inventing Chemistry: Herman Boerhaave and the Reform of the Chemical Arts (Chicago, 2012).

Quotations are taken from Boerhaave, A New Method, 1: 194. This exposition was translated - with poetic licence - from idem, Institutiones et experimenta chemiae, 1: 146-147. For his authorised version of the usefulness of chemistry to medicine, see Boerhaave, Elementa chemiae, 1: 83-84; idem, Elements of Chemistry, trans. Timothy Dallowe (London, 1735), 1: 52-53.

31 Both Boerhaave and Gaubius owned a copy of Stahl's Fundamenta chymiae dogmaticae et experimentalis (Nuremberg, 1723) in their private libraries, as recorded in the auction catalogues "Bibliotheca Boerhaaviana sive catalogus librorum instructissimae bibliothecae viri summi D. Hermanni Boerhaave" (Leiden, 1739), 56; and "Bibliotheca Gaubiana sive Catalogus librorum viri celeberrimi Hieronymi Davidis Gaubii” (Leiden, 1783), 65. On Stahl countering iatrochemical perspectives, see for example Ku-ming Chang, "Fermentation, Phlogiston and Matter Theory: Chemistry and Natural Philosophy in Georg Ernst Stahl's Zymotechnia Fundamentalis," Early Science and Medicine, 7 (2002), 31-63. Boerhaave, Elementa chemiae, 1: 29; idem, Elements of Chemistry, 1: 18. Here Boerhaave specifically suggested that his students read Hoffmann, Observationum physico-chymicarum (Halle, 1722). 
nents within the waters. ${ }^{34}$ Dutch medical professors and their students turned their attention to the body itself, and recognised that in order to explain phenomena in the human body one required chemistry, in particular chemistry of blood.

Gaubius was no exception. He performed many experiments on blood, first and foremost to uncover what he called the "constituent parts." In this demonstration, Gaubius warned his students that appearances could be deceiving. Although to the naked eye blood seemed homogeneous, chemical experiments revealed it was, in fact, made up of different substances. ${ }^{35}$ Gaubius showed students how blood drawn from a healthy person and poured in a bowl was of a "uniform dark and red colour, unctuous and glutinous to the touch." Left to rest, however, it would start to coagulate and split into three parts: one ruby-coloured, hard part, known as crassamentum (i.e., thickness), another white and watery part called serum (whey), and finally a fibre "of a membraneous texture." The apparent homogeneous fluid of blood was, thus, in fact, an amalgamation of parts, which could be identified according to the process of decomposition. As Gaubius summarised in his medical lectures, "it is evident that, besides the spirit [i.e., the smell] of the blood, there are three different constituent parts, the serum, the red blood, and the fibre." ${ }^{36}$

Experimentation did not stop there. In another experiment, Gaubius collected a quantity of healthy blood in a clean glass vessel - so that the transformation might be clearly observed - and subjected it to distillation at different temperatures. This process produced four basic elements: water, bitter oil, volatile salt, and black earth. ${ }^{37}$ Gaubius assigned great significance to this experiment, because it not only revealed the hidden elements in blood, but also informed about the elements that constitute the body as a whole. He argued that the human body consisted of fluids and solids, all constituted by four elements: water, salt, earth and phlogiston - a substance chemists believed to exist in all combustible bodies, which was released through burning. ${ }^{38}$ The

34 Victor D. Boantza and Leslie Tomory, “The 'Subtile Aereal Spirit of Fountains': Mineral Waters and the History of Pneumatic Chemistry," Early Science and Medicine, 21 (2016), 303-331, at 319-322.

35 In 1731 the Leiden Ordines lectionum listed Gaubius' lectures as "naturam Humorum corporis humani experimentis Chemicis;" see P.C. Molhuysen, Bronnen tot de geschiedenis der Leidsche Universiteit, 7 vols. (The Hague, 1913-1924), 5:39.

36 Gaubius, Institutiones, 16o: "Unde liquet, dari in sanguine, praeter spiritum, triplicem materiem contrectabilem, serum, rubrum \& fibram." Cp. idem, Institutions, 106.

37 Ibid., 103-106.

38 The term phlogiston was derived from the Greek phlogistós, "set on fire." For a good reappraisal of the phlogiston theory, see Hasok Chang, Is Water $\mathrm{H}_{2} \mathrm{O}$ ? Evidence, Realism and 
proportion of the principle of water in relation to the other elements imparted fluidity to bodily liquids and flexibility to solid parts. Similarly, the principle of earth assigned the quality of thickness to the fluids, and of firmness to the solids. Bones, for example, were considered to consist almost exclusively of earth, and to be devoid of water. The serum was mostly water, the red crassamentum mostly phlogiston, and the fibre mostly earth and salt. Gaubius believed, then, that he could understand the general physiology of the human body through the analysis of blood.

Gaubius' understanding of the chemical make-up of the animal body was essentially principlist (as opposed to compositionist). Historian of chemistry Robert Siegfried has shown that compositionist explanations of matter were based on the presumption of immutable and basic chemical substances. These chemical substances could be combined and separated, yet they remained intact in themselves and did not change their nature in the process. ${ }^{39}$ Principlism, on the other hand, was a system formed around the concept of principles, namely fundamental substances that imparted characteristic properties to other substances. According to Hasok Chang, principlism had three defining epistemic activities: first, classifying substances according to observable properties; second, explaining the properties of substances by reference to principles; and lastly, effecting transformations of substances by the application (or withdrawal) of principles. ${ }^{40}$ Gaubius' perception of blood and the human body was clearly based on the notion of four principles which actively modified bodily fluids and solids. For example, he referred to phlogiston as "the inflammable part, the principle of heat and light," which gave tenacity to solids and fluids. ${ }^{41}$ The principle of water imparted fluidity to blood, whereas the principle of earth lent it solidity. In a unique constellation, then, the principles accounted for blood and its properties. Gaubius spoke of blood's "own particular nature" or propria natura. 42 The Latin proprius ("one's own" or "particular") provided the root for the concept of 'property' as an attribute or characteristic of a substance. ${ }^{43}$ Gaubius described the chemical properties typical of blood,

Pluralism (Dordrecht, 2012), 1-70.

Robert Siegfried, From Elements to Atoms: A History of Chemical Composition (Philadelphia, 2002).

40 Hasok Chang, "Compositionism as a Dominant Way of Knowing in Modern Chemistry," History of Science, 49 (2011), 247-268; Chang, Is Water $\mathrm{H}_{2} \mathrm{O}$ ?, 37-42. Chang prefers to use the term 'principlist' over 'principalist,' on the grounds that it refers to principles, not principals.

Gaubius, Institutiones, 57: "Inflammabile, coloris calorisque sedes." Idem, Institutions, 37.

Nalini Bhushan, “What is a Chemical Property?” Synthese, 155 (2007), 293-305. 
such as viscosity: the state of having a thick and sticky consistency between solid and fluid. In describing blood, Gaubius referenced the principles of water, phlogiston, salt, and earth, which all imparted characteristic properties to the red fluid. ${ }^{4}$

Gaubius' principlist chemistry proved highly successful in explaining pathological phenomena, which he structured in a coherent system. Gaubius was convinced that solidity, or the force of cohesion, was intrinsic to the elements of water and earth, which was also responsible for the strength of cohesion and the scale of fluidity. This force of cohesion differed from one bodily fluid to another, and was influenced by a person's age, sex, temperament, and way of life. For example, blood was different from milk, because by circulation and air "an acescent [i.e., acid] salt is turned into an alcalescent [alkaline], a fermentible [sic] into a putrescible; the phlogiston is more evolved, the earth condensed." ${ }^{45}$ In some cases, however, the force of cohesion could be excessive (causing viscidity and toughness) or deficient (producing tenuity and thinness). If someone had consumed too much glutinous food, the level of crassamentum would rise in disproportion to the serum, and even cohere to earth elements. The blood would circulate more slowly, stagnate, obstruct, and potentially cause a tumour. By contrast, if a person drank too much, the resulting superfluous water in the serum could lead to haemorrhages. ${ }^{46}$

The rise of chemistry in eighteenth-century medicine radically transformed perceptions of bodily fluids such as blood. Thinking about their constituent parts and principles not only allowed Gaubius to investigate blood more closely, but it also enabled him to theorise about blood in its varying physiological and pathological states. Thus, Boerhaave's and Gaubius' experiments on blood reflected a growing optimism among physicians about the use of new methods in the investigation of the human body. ${ }^{47}$

\section{Haematology}

Blood chemistry did not immediately win the hearts and minds of the entire medical profession, but was confronted with collegial scepticism and rivalling methods. The fact that chemical analyses changed the material appearance of

\footnotetext{
44 Gaubius, Institutions, 37-38, 85-86.

45 Ibid., 161: "sal acescens in alcalescentem, fermentabile in putrescibile, mutatur, phlogiston magis evolvitur, terra densatur." Idem, Institutions, 107.

46 Ibid., 83-89.

47 Conrad et al., The Western Medical Tradition, 371-376.
} 
blood led some physicians to doubt the validity of the experimental results. The most outspoken of these critics was Thomas Schwencke (see fig. 4), who published a systematic study of blood titled Haematologia, sive sanguinis historia (1743). ${ }^{48}$ Schwencke agreed that physicians ought to study blood, because it played a crucial role in the assessment of patients' medical conditions. Schwencke's haematology was, therefore, not only aimed towards the acquisition of new knowledge about blood, but was also directly and actively involved in the treatment of blood, including the advantages and disadvantages of phlebotomy and the medicines to treat wounds and stop the bleeding. Haematology, in other words, was supposed to be applicable in medical practice. In his studies, Schwencke closely observed the colours and smells during coagulation, using hydrometers and thermometers to measure the density and temperature of the blood in different places (arteries and veins) and circumstances. But as we shall see, measuring was also crucial to Schwencke's haematology, because it allowed him to question the usefulness of chemistry for the analysis of blood.

The reason why Schwencke began to doubt the chemical approach was because his medical career had taken him into very different directions from those Boerhaave and Gaubius had followed. His was a practical, hands-on career, not the kind of 'armchair medicine' often pursued by university professors. Born in the city of Maastricht, Schwencke had begun his medical studies in surgery and pharmacy before he matriculated at Leiden University in 1712. After defending his dissertation on saliva in 1715 Schwencke began working as a physician in The Hague. His practice in medicine and obstetrics soon earned him a fine reputation, and in 1723 the town council appointed him professor of anatomy and surgery. His duties included the teaching of anatomy to local midwives and surgeons. In 1737 he was also installed as court physician to Prince Karl Christian and Princess Carolina van Nassau-Weilburg, brotherin-law to and sister of Stadtholder William V (1745-1808) respectively.99 Another of Schwencke's famous patients was Adrienne Marguerite Huguetan, Countess de Nassau La Lecq: in $175^{2}$ he paid her thirteen visits and held 38 consultations, for which he received 84 guilders. ${ }^{50}$

48 Schwencke, Haematologia. Schwencke first coined the term haematology, according to Harry F.P. Hillen, "De eerste Nederlandse hematoloog: Thomas Schwencke (1694-1767)," Nederlands Tijdschrift voor Hematologie, 7 (2010), 17-20.

49 Eduard Sandifort, "Levensbeschryving van den Hooggeleerden Heere Thomas Schwencke," in idem, Natuur- en genees-kundige bibliotheek, 11 vols. (The Hague, 1765-1775), 3: 429-436. Eduard van Biema, Les Huguetan de Mercier et de Vrijhoeven: histoire d'une famille de financiers huguenots de la fin du XVIIe jusqu'à la moitié du XVIII siècle (The Hague, 1918), 58. 


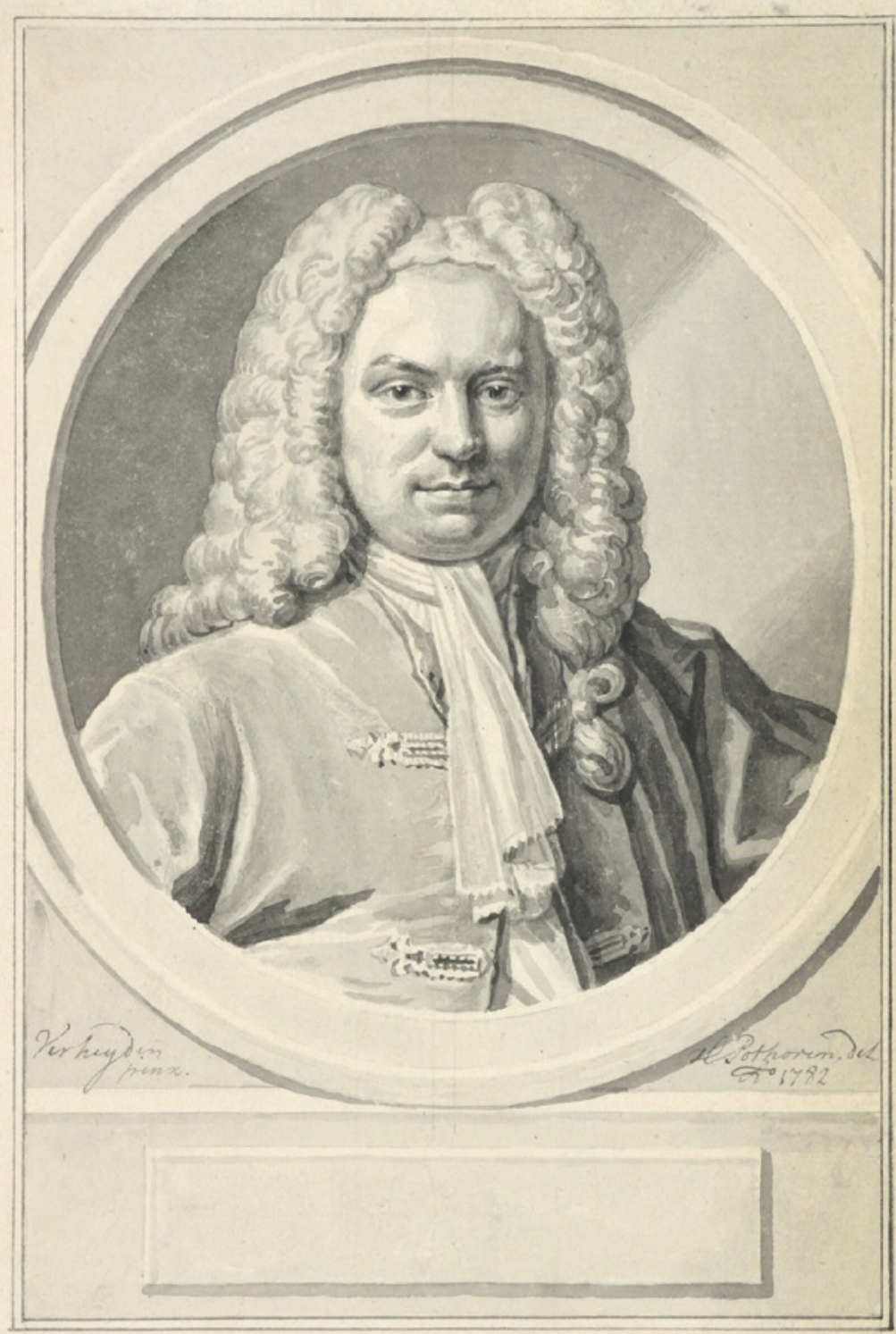

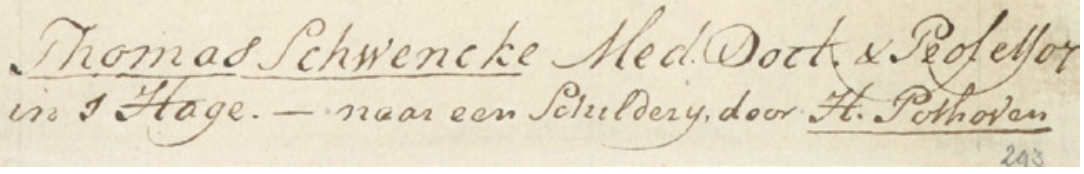

FIGURE 4 Hendrik Pothoven, after a painting by Verheyden, portrait of Thomas Schwencke, 1782. MUNICIPAL ARCHIVES, THE HAGUE. 
The contrast between Schwencke and Gaubius could not have been greater. Whereas both had studied medicine at Leiden and trained to become physicians, Gaubius hated the practice of medicine. After three years of working as physician in Deventer and Amsterdam, Gaubius was glad to be appointed at Leiden University in 1731 because, as he confessed to a colleague, it relieved him of his "aversion of the very tiresome practice." ${ }^{1}$ To his close friend António Sanches (1699-1783) he confessed that he disliked medical practice and public service, because he felt that it tied him down. ${ }^{52}$ Indeed, when he was appointed court physician to William v in 1761 , Gaubius admitted that "I would have liked to be excused at the beginning of old age, to be able to only attend to my peaceful profession joined with a practice much less bristled with thorns." 33 While Gaubius sought to explain pathological theory to students, Schwencke devoted most of his energy to surgical practice. Based on his experiences, for example, Schwencke presented six different ways to stem bleeding, namely, by fire, alcohol, stitches, various bandages, and the external application of agaric, a tree mushroom. ${ }^{54}$ Schwencke's hands-on approach to medicine meant that his focus was more directed towards successful treatment than Gaubius', who preferred developing and teaching theories of pathology.

Central to Schwencke's haematology were his detailed descriptions of blood, in particular the many weight and density measurements he took. Schwencke closely observed how the healthy blood of a strong man, once collected in a bowl, naturally separated in two parts serum and one part cruor (i.e., red blood). ${ }^{55}$ Schwencke also compared the respective ratios of density in blood and water, using a hydrometer built by the Amsterdam instrument-maker Daniel Fahrenheit of thermometer fame (1686-1736). Fahrenheit's hydrometer consisted of two glass spheres connected by a cylinder (see fig. 5 ). The lower sphere was filled with quicksilver. Schwencke then lowered the instrument into a large cylindrical vessel filled with blood and observed how deep it sank, repeating the experiment with the individual constituent parts of blood. He discovered that water weighed 1110 grains, serum of blood 1142 grains (1/34 heavier than water), red blood 1204 grains (1/12 heavier than water), and ordinary blood

Gaubius to Albrecht von Haller, 23 March 1743 in Sophia W. Hamers-van Duynen, Hieronymus David Gaubius (1705-1780): Zijn correspondentie met Antonio Nunes Ribeiro Sanches en andere tijdgenoten (Assen and Amsterdam, 1978), 181-183. Gaubius to Antonio Sanches, 9 March 1748, ibid., 95-97.

53 Gaubius to Sanches, 23 September 1761, ibid., 123-125.

54 Thomas Schwencke, "Aanmerkingen over verscheide manieren van bloedstelpen, en de voornaamste bloedstelpende middelen in de heelkunde," Verhandelingen van de Hollandse Maatschappy der Weetenschappen, 2 (1755), 225-250. 


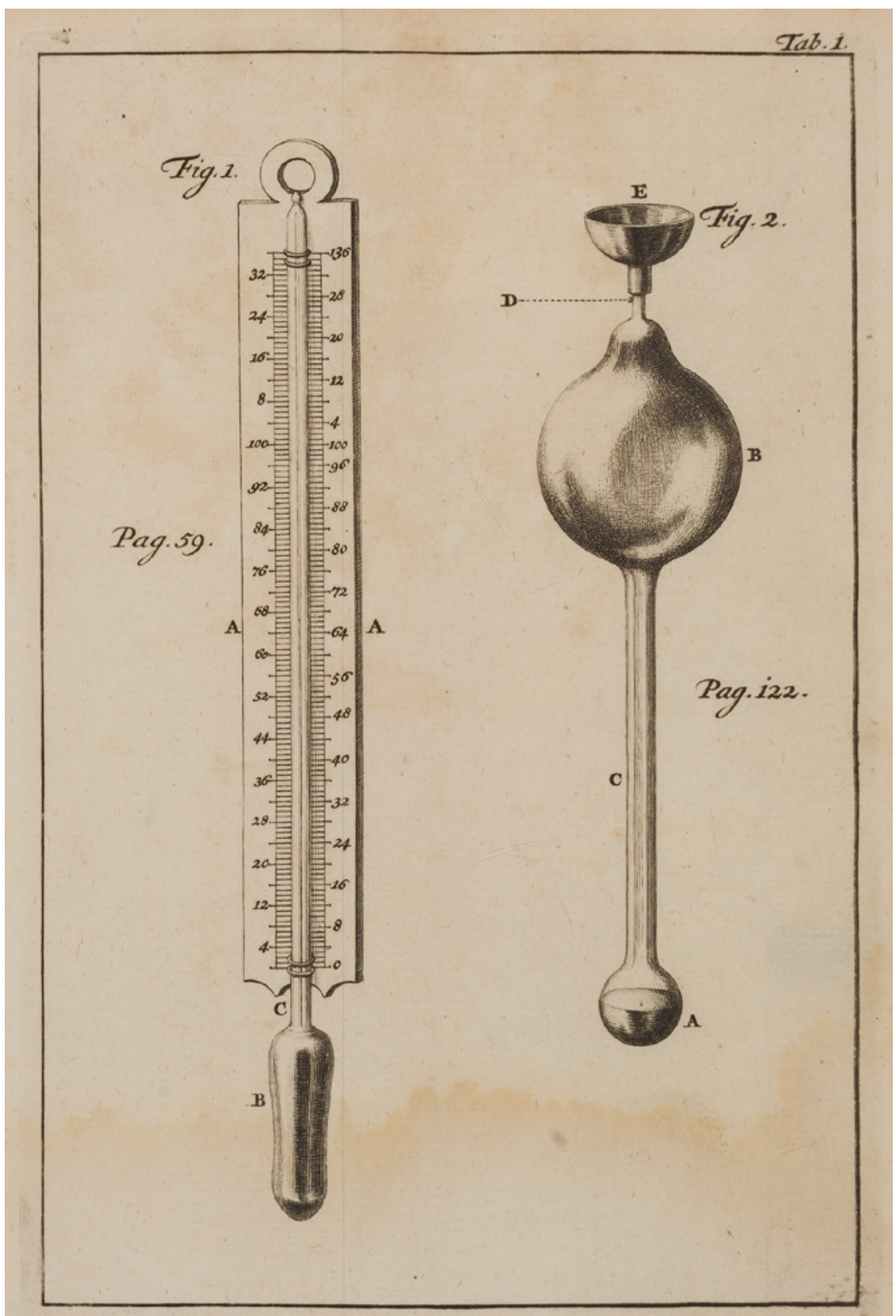

FIGURE 5 Thermometer (left) and hydrometer (right) in Schwencke, Haematologia (The Hague, 1743). UNIVERSITY LIBRARY, GRONINGEN. 
1173 grains. When he measured the densities again using different blood samples, he discovered that these ratios differed with the donor's age and sex. ${ }^{56}$

Microscopy also formed an important part of Schwencke's haematology. He incorporated Antonie van Leeuwenhoek's (1632-1723) findings on the microscopic size and shape of red blood globules into his Haematologia (see fig. 6). Leeuwenhoek had found that red blood consisted of heavy, elastic, and round globules of a red, purple, or black colour. Schwencke argued that one red globule consisted of a cluster of six serum globules, together gaining weight and darkness, but preserving the same size. Furthermore, he believed that every serum globule was composed of six chyle globules. One red blood globule therefore consisted of 36 chyle globules, stuck together by an inherent, elastic force emanating from each individual globule. ${ }^{57}$

Finally, Schwencke gained new knowledge about blood and coagulation by means of measuring temperature. His efforts were part of a wider development: Hasok Chang has shown how natural philosophers all faced the problem establishing fixed points in thermometry, and debated the use and applicability of thermometers. ${ }^{58}$ John Powers has shown that Boerhaave integrated Fahrenheit's thermometer in his chemical lectures, and that other chemistry instructors followed suit. ${ }^{59}$ We know indeed from Gaubius' post-mortem inventory that he owned a number of thermometers, one of which was graduated in Fahrenheit, Wachendorff and Réaumur. ${ }^{60} \mathrm{He}$ also used the Fahrenheit thermometer in experiments and demonstrations, as student lecture notes attest. ${ }^{61}$ Gaubius observed, for example, that blood serum "by the heat of 150 Farenheit's [sic] thermometer, is suddenly converted, without much dissipation, into a whitish scissile mass, like the white of an egg." ${ }^{62}$

\footnotetext{
$56 \quad$ Ibid., 200-209.

57 Ibid., $176-180$.

58 Hasok Chang, Inventing Temperature: Measurement and Scientific Progress (Oxford, 2004).

59 John C. Powers, "Measuring Fire: Herman Boerhaave and the Introduction of Thermometry into Chemistry," Osiris, 29 (2014), 158-177.

6o [Anonymous], "Musei Gaubiani pars sive Catalogus partis supellectilis, qua usus est vir celeberrimus H.D. Gaubius" (Leiden, 1783), 31. Besides Fahrenheit, these scales of temperature were named after Evert Jacob van Wachendorff (1703-1758), professor of medicine, botany and chemistry at Utrecht University, and French naturalist René-Antoine Ferchault de Réaumur (1683-1757).

$61 \quad$ "Praelectiones publicae chemicae," vol. 1, pp. 38, 39, 101, 102, etc., "thermometrum Fahrenheitianum."

62 Gaubius, Institutiones, 157: "igne 150 graduum thermometri Fahrenheitiani, instar albuminis ovi, cito, absque multa dissipatione, concrescit in massam albidam, scissilem." Idem, Institutions, 104.
} 


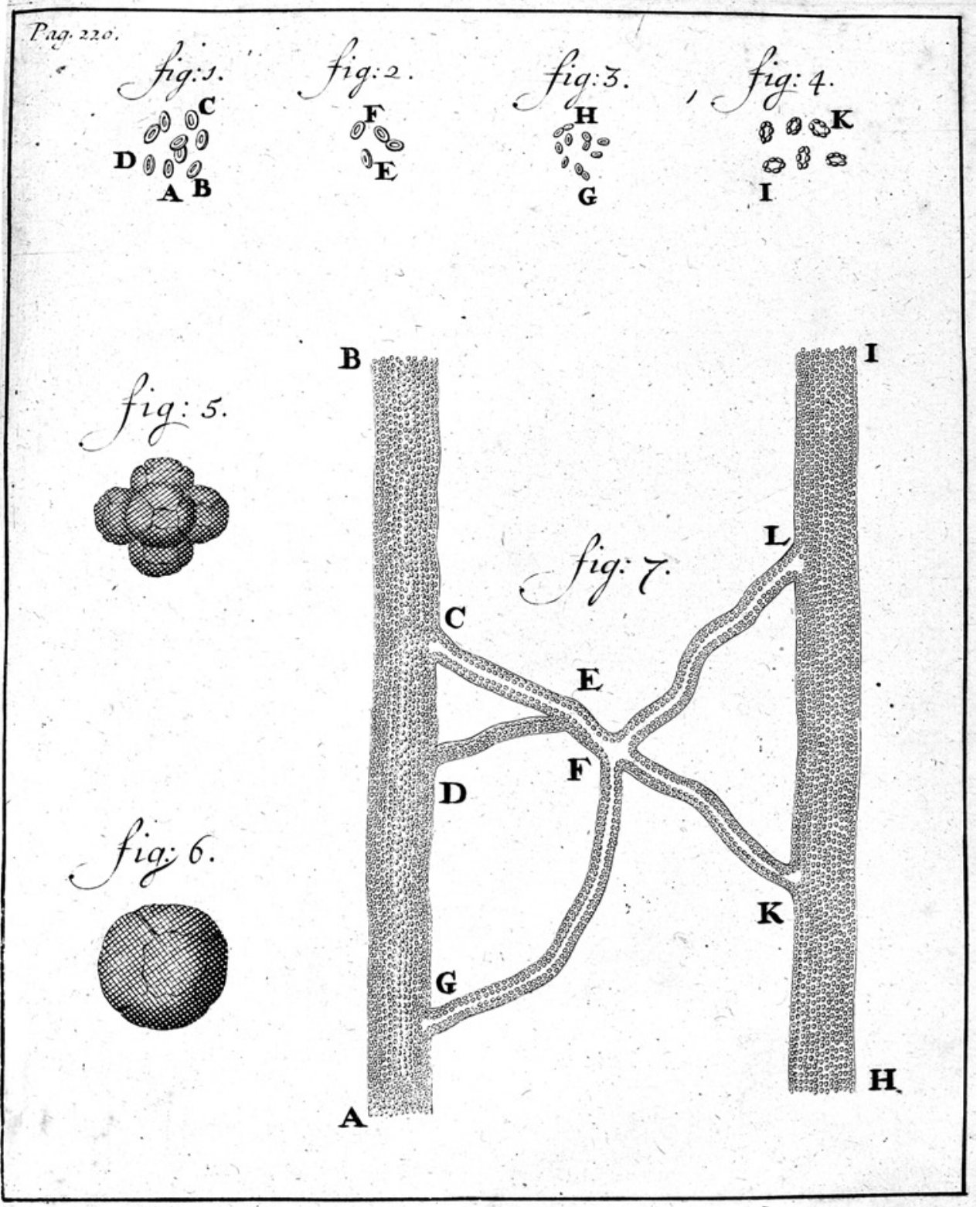

FIGURE 6 Blood corpuscles observed through a microscope, in Antonie van Leeuwenhoek, Arcana natura detecta (Leiden, 1719). Wellcome Collection <https://wellcomecollec tion.org >, LICENSED UNDER CC-BY 4.0. 
Schwencke, too, argued that the only way in which degrees of heat could be properly measured was with a thermometer. He regarded the quicksilver thermometer as the "true indicator of the heat," but he used it in quite a different manner. ${ }^{63}$ In 1731 , Schwencke performed a number of experiments on the blood of oxen and cows with the thermometer. He took the temperature simultaneously in the carotid artery and jugular vein, measuring 97 and 94 degrees Fahrenheit respectively, and concluded that the body's heat was dependent upon the movement and friction of blood. Excitement caused the pulse to throb more rapidly as the heat increased. ${ }^{64}$ Schwencke established that a healthy person had a temperature of 96 degrees, and he reasoned that there existed a correlation between body temperature, mental state, and disease. Future physicians, Schwencke argued, ought to systematically measure the temperature of patients suffering from any disease, which would greatly improve diagnostics. ${ }^{65}$ Introducing the term of haematology, Schwencke squarely placed this study of blood within the context of what has been called "the quantifying spirit." 66 The extensive measurements of blood density and temperature, and microscopic observations of blood globules, exemplify the early modern passion to order and systematise, to measure and calculate.

\section{Chemistry Contested}

But measurements also led Thomas Schwencke to question the chemical approach to the study of blood. As part of his study on the material disposition of blood, Schwencke reproduced Gaubius' chemical experiments. Just like Gaubius had done, Schwencke drew six ounces of blood from a healthy person and distilled it in a glass alembic, indeed producing water, a bitter oil, a volatile salt, a black and malodorous oil, and a black earth. ${ }^{67}$ Yet when he weighed the various elements, he discovered that water made up a staggering $7 / 8$ parts of the blood, instead of the two thirds obtained after natural coagulation. Struck by the high degree of variability that chemistry had produced in vitro Schwencke began to doubt the applicability of chemistry in vivo. How did the proportion

\footnotetext{
63 Schwencke, Haematologia, xi: "utpote solam judicem caloris." Idem, Verhandeling van het bloed, xix.

64 Ibid., 49 .

65 Ibid., xix-xx.

66 Tore Frängsmyr, John L. Heilbron, and Robin E. Rider, eds., The Quantifying Spirit in the 18th Century (Berkeley, 1990).

67 Schwencke, Verhandeling van het bloed, 246-247.
} 
of two thirds serum and one third cruor by hydrometry align with the very different division obtained by distillation? From this Schwencke argued that chemical operation by fire not only divided some of the blood's elements, but also produced new elements not found in the living body. No matter how carefully chemists attempted to reassemble these ingredients, he claimed, they would never be able to recombine them to form human blood, not in colour, smell, or any other property.

Schwencke also discredited chemistry by pointing out the innumerable differences between chemistry and nature. In procreation, nature can produce all body parts of an infant, solely on the basis of blood and mother's milk. This process was yet to be explained by chemistry. Furthermore, physicians commonly agreed that blood was the mother of all bodily fluids. Yet chemists could produce not one of them. Surely, Schwencke argued, the chemist cannot afford to use only fire for experimentation, but would require the use of a thousand more processes, as many as there were parts in the body. As he warned his readers, "although we have presented here the Chemical analysis of the blood, no one will believe that we have therefore demonstrated and argued the nature and quality of the same." 68

The debate between advocates for and opponents to blood chemistry can be explained with the help of the contrasting contemporary principlist and compositionist understandings of matter. I argue that Schwencke's opposition to blood chemistry stemmed from his preference for compositionism. In Schwencke's view, chemical processes were mere processes of re-grouping basic components - a view also emerging in his understanding of the blood globules. The impossibility to reconstruct blood, or any other bodily fluid, conflicted with the notion of his 'building block' compositionist understanding of matter. This ideological difference between Gaubius and Schwencke was, however, not as clear-cut as it may seem, especially because Gaubius' principlist blood chemistry included (for lack of a better word) some compositionist elements. Gaubius' analysis of blood as a substance consisting of constituent parts did not directly explain the notion of principles of water, phlogiston, salt, and earth. As Albrecht von Haller later commented, "these are not the natural but factitious Principles of the Blood, produced or made by the Intensity of Fire." ${ }^{69}$ The debate between principlist and compositionist understandings of

68 Schwencke, Haematologia, 153: "Quamvis ergo sanguinis examen Chemicum tradiderim, nemo tamen credat, me inde naturam sanguinis voluisse explicare." Idem, Verhandeling van het bloed, 252.

69 von Haller, Academical Lectures, 2: 167-168. In the original Latin, von Haller made a distinction between particles brought about by natural body heat, and those made by the 
nature continued throughout the century, ultimately leading to a compositionist chemistry at the turn of the nineteenth century.

Schwencke's concerns about the essential difference between blood in vitro and in vivo also found echoes outside the Dutch Republic. One of the most notable critics of blood chemistry was the French physician Théophile de Bordeu (1722-1776), who opined that blood in alembics bore no relation to living blood. Bordeu eventually settled in Paris, where court physician Louis de Lacaze (1703-1765) mobilised his help for the completion of a treatise on the theoretical foundations of medicine. ${ }^{70}$ This work sharply criticised those who obtained knowledge about diseases with the help of the dissection of corpses. If readers really wished to understand "the essential character of a disease," they required information about its course and tested methods of treatment. In other words, the "mechanism of life" could only be understood by the "observation of the living body." ${ }^{11}$ It was the rhythmical throbbing of the arteries that won Bordeu general acclaim. In 1756 he published a book on the pulse, which received positive reviews. The study of the many "species" of the pulse was the observation of living blood and recognition of the signs of diseases. Looking for ways of diagnosing and treating patients, then, both Schwencke and Bordeu focused their attention on the symptoms and circumstances of living blood. 72

Bordeu soon recognised that feeling the pulse produced quite different results from distilling blood serum. Whereas Dutch chemists had shown that serum putrefied under moderate heat - a phenomenon Boerhaave considered the cause of many diseases ${ }^{73}$ - Bordeu observed that "the blood in the living body never shows any signs of putridity or acrimony, and that it is even inca-

intensity of fire, see Praelectiones, 2: 312. "Id nobis sufficit, demonstrari per id experimentum, inesse sanguini particulas alias aliis mobiliores, quarum aliquae solo calore hominis sani eleventur, aliae igni leniori, aliae demum ultima vehementia ignis mobiles atque volatiles reddi possint."

70 Although ascribed to Bordeu, the treatise appeared under Louis de Lacaze's name, titled Idée de l'homme physique et moral: pour servir d'introduction à un traité de médecine (Paris, 1755); Elizabeth A. Williams, A Cultural History of Medical Vitalism in Enlightenment Montpellier (Aldershot, 2003); Anne C. Vila, Enlightenment and Pathology: Sensibility in the Literature and Medicine of Eighteenth-Century France (Baltimore, 1998). Lacaze, Idée de l'homme, 9-10: "le caractere essentiel de la maladie [...] la méchanique de la vie [...] l'observation du corps vivant."

72 Théophile de Bordeu, Recherches sur le pouls, par rapport aux crises (Paris, 1756); idem, Inquiries Concerning the Varieties of the Pulse: And the Particular Crisis Each More Especially Indicates (London, 1764); Vila, Enlightenment and Pathology, 59. 
pable of any fermentation inside it. This completely precludes all notions about the bitterness of fluids contained in their vessels, and at the same time eliminates all the applications that supposedly can be made of the changes observed in dead fluids on the various changes that are consequently believed to happen in various stages of an illness, and on the liquids of the living body."74 For Bordeu, then, all changes observed in blood through chemistry were useless, because they had no relation to the properties of living blood, whether diseased or healthy. Some physicians' practical approach to medicine led them to doubt the necessity of chemistry for an understanding of bodily fluids in vivo.

In Gaubius' eyes, however, blood was not either dead or alive. Rather, he perceived latent powers inherent in bodily materials like blood. Besides recognising the existence of an immaterial and eternal soul, Gaubius developed a material theory of life in which the constituent parts of the body acted on and explained physiological phenomena. The principles of water, phlogiston, salt and earth explained how it was possible for blood to cohere, separate, and coagulate, and hence, to nurse and nourish. These principles within blood, in other words, explained the life of the body. A similar threefold explanation applied to the relation between body and soul: Gaubius envisioned an enormôn in the nerves in order to bridge the dichotomy between body and soul, since this principle, or agent of arousal, was responsible for movements of the body, as well as for transmitting bodily changes via the senses to the mind. ${ }^{75} \mathrm{In}$ short, Gaubius saw no disjunction between blood as a material that underwent changes in various pathological circumstances, and blood as a fluid embodying vital functions of the body. In his chemical lectures, for example, he told his students that "you have seen, I hope, that the experiments with blood have taught you its parts, properties, nature, mutability, origin, and forces. This was the matter of more than forty lectures, and no wonder, for blood is the universal liquid of our microcosm; from which Moses has said that in it is the living soul, and he forbade the use of blood." ${ }^{76}$

74 Lacaze, Idée de l'homme, 44: "le sang dans le corps vivant ne donne jamais des marques de putridité ni d'acrimonie, \& même qu'il y est incapable de toute fermentation: ce qui écarte absolument toutes les idées d'acrimonie des liqeurs contenues dans leurs vaisseaux, \& détruit en même temps toutes les applications qu'on a prétendu pourvoir faire des changements observés dans les liqueurs mortes, aux divers changements qu'on croit par'là pourvoir arriver dans les divers états de maladie, aux liqueurs du corps vivant." Lelland J. Rather, Mind and Body in Eighteenth-Century Medicine: A Study Based on Jerome Gaub's De regimine mentis (Berkeley and Los Angeles, 1965), 59-65.

76 "Praelectiones publicae chemicae," vol. 2, p. 273: "Vidistis, spero, experimenta circa sanguinem, ejus partes, proprietates, indolem, mutabilitatem, originem, vires docui. Haec 
Yet such statements carried no small degree of risk: locating life in the blood came dangerously close to materialism and atheism. If the soul was indeed in the blood, how could this spiritual part be regarded as immortal? The career of the French physician Julien Offray de La Mettrie (1709-1751) aptly illustrates the dangers of locating the soul in the blood. La Mettrie visited Leiden in the 1730 s and 1740s, attended lectures by Boerhaave and Gaubius, and disseminated Boerhaave's ideas with the publication and translation of several of his works. Inspired by Gaubius' lecture De regimine mentis (1747), on the harmful and beneficial effects of the body on the soul, La Mettrie published his book L'homme machine (1748), in which he described the human body as "a clock, but huge and built with so much artifice and ability." Discussing the phenomenon of sleeping, he wrote that "if the blood circulates too fast, the soul cannot sleep. If the Soul is too agitated, the Blood cannot calm down; it gallops through the veins with such a sound one can hear."77 Although La Mettrie did not eliminate the soul altogether by reducing life to matter alone, he did present it as a secondary quality of the body, largely dependent on physiological processes. In this philosophy the soul still existed, but was no longer a metaphysical entity that would survive the body after its death. ${ }^{78}$ For many, La Mettrie's materialism had gone one step too far, especially since his treatise was written in the vernacular and directed at a wide audience. La Mettrie was duly accused of atheism, exiled, and his book banned from the market.

Gaubius struggled with this legacy since, indeed, his own views on the interrelation between blood and soul appeared eerily similar to La Mettrie's. Although Gaubius firmly stressed the existence of the eternal soul, he had lectured on the disturbances that occurred simultaneously in soul and body, pointing out that the "life of the Human Body indisputably consists of some determined motion of liquids through the vessels."79 Gaubius nonetheless

fuit materies ultra 40 praelectionum, nec mirum, nam sanguis est catholicum illud liquidum nostri microcosmi; unde Moses, cum interdixit usum sanguinis, direbat, quia in eo est animalis anima."

Julien Offray de la Mettrie, L'homme machine (Leiden, 1748), 93, 12: "le corps humain est une horloge, mais immense, \& construite avec tant d'Artifice \& d'Habilité." “La circulation se fait elle avec trop de vitellese? l'Ame ne peut dormir. L'Ame est-elle trop agitée, le Sang ne peut se calmer; il galope dans les veines avec un bruit qu'on entend." See also Jessica Riskin, The Restless Clock: A History of the Centuries-Long Argument over What Makes Living Things Tick (Chicago, 2015).

78 Charles T. Wolfe, Materialism: A Historico-Philosophical Introduction (Dordrecht, 2016), 10, 52-53; Thomson, Bodies of Thought, 180-189.

79 Hieronymus David Gaubius, Oratio de vana vitae longae, a chemicis promissae, exspectatione (Leiden, 1734), 12. "Vitam nimirura Corporis Humani in determinato quodam humo- 
managed to avoid controversy, by writing within a strictly medical context and in Latin, which ensured that his ideas were only available to an educated audience; by admitting the limits of his knowledge; and by keeping La Mettrie at a distance. In 1763, for example, in his lecture on the healthy influences of the soul on the body, Gaubius publicly condemned La Mettrie: "I do indeed regret bitterly that a little Frenchman - a Mimus or Momus? - brought forth a repulsive offspring, to wit, his mechanical man." 80 In the same address Gaubius expressed his views on the physiological mechanism of the interaction between body and soul, this time stressing that, while physical conditions had their effects on the mind, the soul could equally have beneficial and harmful effects on the body. However, when his colleague Paulus de Wind (1714-1771), a physician from Middelburg, asked him in a letter to elaborate further on the connections between the soul and the body, Gaubius struggled to provide an adequate answer: regarding the "phenomena of the human oeconomy, as Physician or Medical man I cannot approve, for I do not know what kind of idea to connect to the Soul that is in the blood and distinct from Spirit and Body." ${ }^{1}$

\section{Conclusion}

This article has examined the changing medical perceptions of blood and the development of rivalling ways to study this bodily fluid in the early eighteenth century in the Dutch Republic, especially the remarkable developments in blood chemistry and haematology not previously considered in historiography. Prompted by the works of Herman Boerhaave, a school of Dutch physicians conducted investigations into the living fluids to answer questions in physiology and pathology.

Understanding the nature of blood was no straightforward enterprise, as new research possibilities complicated the answer as to what constituted valid knowledge about blood. ${ }^{82}$ To understand blood and its properties, physicians combined new practical skills of observation, measurement, and chemical ex-

rum per canales motu consistere." Idem, Institutions, 184-185.

8o Hieronymus David Gaubius, Sermo academicus de regimine mentis quod medicorum est (Leiden, 1763), 2: "Doleo equidem vehementer, Mimum, an Momum? Gallulum [...] putidum automatis sui humani scilicet! partum edidisse." Rather, Mind and Body, 115.

81 Gaubius to Paulus de Wind, 9 August $175^{8}$ in Hamers-van Duynen, Hieronymus David Gaubius, 216: "ter explicatie van de voorkomende phaenomena Oeconomia humana, kan ik mede niet approbeeren, als Physicus of Medicus, niet wetende wat voor eene idee vast te maken aan de Siele die in het bloed is, onderscheyden van Geest en Lighaam." 
perimentation with theoretical knowledge about the animal oeconomy. Some were convinced that medicine necessitated blood chemistry, because hydraulic and hydrostatic approaches to the living body could not explain the properties and changes in blood and other bodily fluids. While these mechanist views were, therefore, limited, blood chemistry held out the promise of truly understanding the nature of blood.

Ultimately we can trace an Enlightenment debate on the nature of blood. Physicians had first perceived blood to be an ordinary fluid, focussing on its broad range of sensible and physical properties, e.g. their visible transformations, like coagulation. At the turn of the eighteenth century, however, we can see that the materiality of blood was understood on different levels of inquiry. ${ }^{83}$ Some characteristics of blood, such as its volume, weight, and temperature, were observed thanks to microscopes, thermometers, and hydrometers. Yet, at another level of inquiry, blood was considered to be composed of constituent parts, and its properties could be explained in reference to four principles. Thanks to chemistry various bodily fluids and their variations became an object of conceptual inquiry, which was employed in order to improve existing theories of physiology and pathology. Whereas Thomas Schwencke argued that blood in vitro was fundamentally different from blood in vivo, Hieronymus Gaubius merely saw differences in state and composition while also recognising blood as vital matter.

The different approaches advanced here are crucial to our understanding of how and why medical researchers began to explore the material and physical properties of the human body. Historiography on the Enlightenment commonly equates materialism with atheism, with Julien Offray de La Mettrie as the most commonly mentioned proponent. But as Charles Wolfe has recently emphasised, there existed many different forms of materialism. ${ }^{84}$ And as this article has shown, Dutch physicians also located vital properties in the fluid of blood without adhering to a radical form of materialism. The false binary of materialism and vitalism thus proves rather unhelpful for historiographical attempts to understand blood chemistry in the eighteenth century. Dutch physicians were, in fact, part of a long medical tradition that considered blood and its perambulations in the body the source of life, and a dynamic substance that could be sensed and studied, both in bodies and laboratories.

Moreover, the frequently cited conceptual dichotomy between mechanism and vitalism proves to be false. Focussing on a material such as blood has de-

\footnotetext{
83 Cf. Ursula Klein, "Shifting Ontologies, Changing Classifications: Plant Materials from 1700 to 1830," Studies in History and Philosophy of Science, 36 (2005), 261-329, at 266-267.

84 Wolfe, Materialism.
} 
stabilised the conceptual comfort of opposing mechanist and anti-mechanist models of the body. This article has shown how physicians presented increasingly complex and hybrid forms of mechanism, which included vital properties and active matter, as demonstrated by chemical investigations of blood. Early eighteenth-century chemistry, then, effectively acted as a go-between by blending mechanist, materialist, and vitalist perceptions of the living body within the field of academic medicine. 